\title{
Main Trends in the Development of the Global E-Commerce Market
}

\author{
Ekaterina Merzlyakova*, Irina Ershova, and Evgeniy Bridskiy
}

South-West State University, Department of Finance and credit, 30504050 let Oktyabrya, 94, Kursk, Russia

\begin{abstract}
The advent of Internet technologies has contributed to the spread of e-commerce in many countries around the world. The Russian Federation is also developing rapidly. E-commerce participants are not individual organizations and enterprises. Currently, in all areas in which it is possible, business entities seek to use the options of distribution of goods and services to expand their activities. The activity of citizens in the field of e-commerce is increasing. Research shows high growth rates for ecommerce worldwide. The stable positive dynamics of the industry attracts more and more new participants focused on innovative solutions and new forms of business. The relevance of the topic is due to the need to analyze the trends in the development of commerce and determine its prospects in Russia.
\end{abstract}

The global e-commerce market is booming, with global e-commerce sales up $17.9 \%$ in 2019 to $\$ 3.46$ trillion. The dynamics of the global e-commerce market is shown in Figure 1.

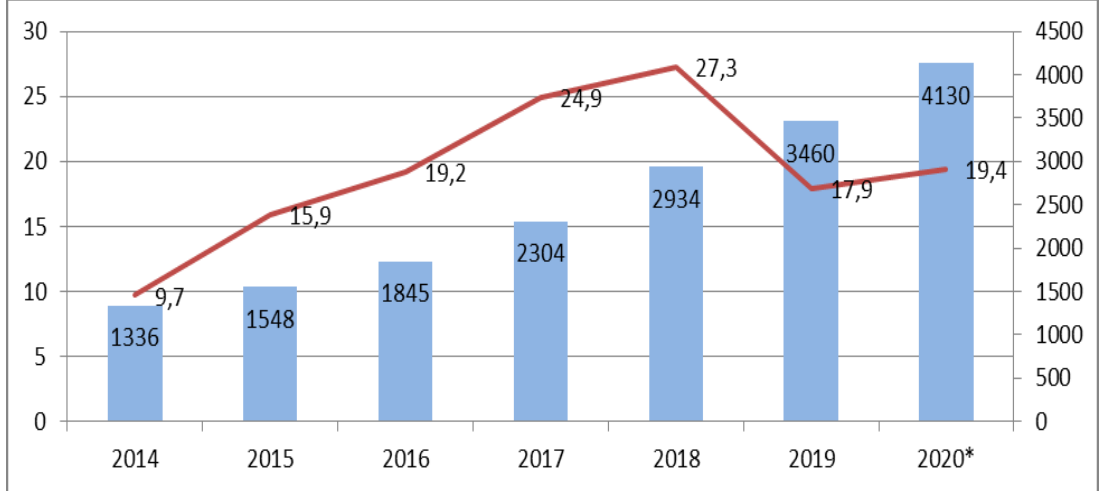

Fig. 1. The volume and growth rate of sales of the global e-commerce market for 2014-2020, billion dollars

\footnotetext{
* Corresponding author: ek_mer@mail.ru
} 
From the data presented, it can be seen that sales in the global e-commerce market are growing. However, the graph of the growth rates attracts attention. So, in 2014-2018. there was an active increase in growth from $9.7 \%$ to $27.3 \%$, then in 2019 there was a decrease in the growth rate to $17.9 \%$, and according to forecasts for 2020 , the value will slightly increase.

The global e-commerce market is developing mainly through two formats: online stores and marketplaces. The sales volumes of the global e-commerce market for 2019, for the most active countries in the world, are presented in Figure 2.

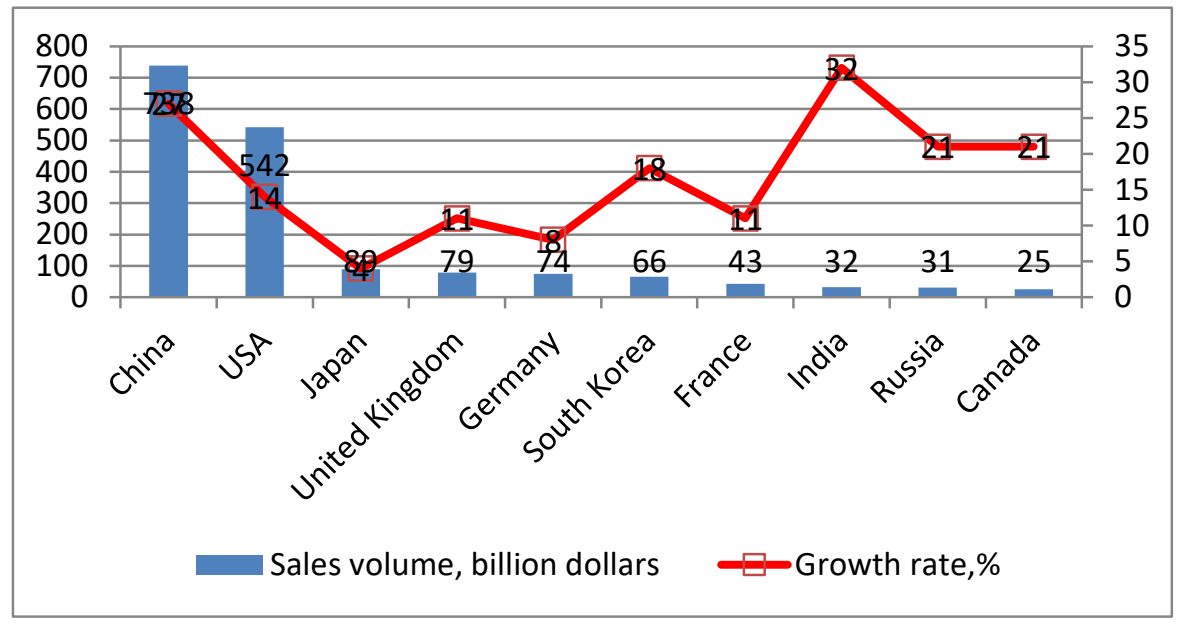

Fig. 2. Volume and growth of the e-commerce market in 2019, billion US dollars

From the presented data, we see that the leaders of the e-commerce market are China and the United States, which account for about $40 \%$ of the total market. At the same time, the highest growth rates are noted in India, Russia and Canada [1].

The first place in terms of sales volume of the e-commerce market is occupied by China, the market volume of which is 738 billion dollars. At the same time, $33 \%$ of purchases are made from mobile devices (tablets and smartphones), 67\% - from stationary computers.

China is the largest e-commerce market in the world, not least because of its population, with over 600 million internet users. At the same time, e-mail marketing has a great success in the Chinese e-commerce market. In a survey, $75 \%$ of consumers said they were ready to make a purchase after they received a special offer in the mail.

According to the monitoring data of the China E-Commerce Research Center, the volume of transactions in the e-commerce market in China in 2019 was 34.8 trillion. yuan, an increase of $16.5 \%$ over 2018 . With the rapid development of e-commerce, problems gradually began to arise that began to limit the development of the B2B model.

Basically, these problems include the following aspects [2]:

1. Problems of product quality and business reputation

In e-commerce, the customer cannot see the product and cannot fully know the product information. In this regard, counterfeits, low-quality products began to appear. Some platforms cannot guarantee food safety, recycled oil explosion, unlicensed operations, etc. And all of this has added to people's fears of the e-commerce platform. Thus, counterfeit products not only affected consumers, but also affected manufacturing companies and inflicted huge losses on them. 


\section{Insufficient oversight of the legal system}

Due to the insufficient time spent developing e-commerce and its fast pace in China, many legal systems are still not perfect. Legal issues arising in e-commerce will also appear in online transactions. It is currently impossible to develop a legal system for e-commerce in one go, only the development of relevant laws and regulations will help to reach consensus, as well as constantly improve and change them in the process of development of e-commerce.

Thus, an accurate understanding of e-commerce and e-payment technologies simultaneously is necessary to address the new challenges posed by the information society. We must take into account the laws and rule systems of the Information Society to ensure that it is always in a positive development.

3. Regional imbalance in the development of electronic commerce.

According to the latest research, the largest players in this segment in terms of revenue were the US (Amazon - first place, EBay - third place, Walmart - fourth place) and China (JD.com - second place, Alibaba - fifth place).

The most popular online retailer by e-commerce sales in China is Alibaba Group. The main activities are B2B trade between companies and online retail; also owns one of the world's largest cloud computing infrastructures and media and entertainment assets. AlibabaGroup's annual revenue is only $20 \%$ of Amazon's annual revenue. However, Alibaba's margins are higher as it acts as a marketplace for independent buyers and sellers, while Amazon sells products directly to consumers and incurs more costs.

In second place is the United States, with an e-commerce market of $\$ 542$ billion. At the same time, $13 \%$ of purchases come from tablets, $15 \%$ - from smartphones, $72 \%$ - from stationary computers. Thus, Americans buy more through computers, less through mobile devices. It should be noted that $72 \%$ of SMEs do not trade online. Despite the fact that there are about 191.1 million online shoppers in the US, only $28 \%$ of small businesses sell their products online. In general, more than half (57.4\%) of American stores operate online. For most American shoppers, it is key to be able to check the availability of a product in a warehouse or in an offline store located near your home.

The United States is the largest country in terms of GDP and the second largest ecommerce market after China with high Internet penetration and a leader in cutting-edge technological innovation. The United States is a large e-commerce market with \$ 542 billion, with American customers among the most active online shoppers in the world. According to Statista, four-fifths of all Internet users in the US (about 80\%) bought at least one product during 2019.

E-commerce shipments by US manufacturers reached \$ 4,106.9 billion in 2019. Total ecommerce sales to wholesalers in the United States, including branches and sales offices, rose $1.3 \%$ to $\$ 2,725$ billion. USA in $2019[3,4]$.

Consider the volume of retail e-commerce and its share in the volume of US retail trade for the period 2015-2019, shown in Table 1.

According to the data obtained, there is a constant growth in both the volume of e-retail commerce and its share in the total volume of retail sales. During the study period, there was an increase in volumes by more than 16 times, as well as an increase in the share in the total volume of retail sales - 9 times. From 2015 to the present, there has been a steady growth in retail e-commerce volumes.

2019 U.S. e-commerce retail sales totaled \$ 542.3 billion, up $10.8 \%$ from 2018 , the highest growth rate since 2015. Total retail sales in 2019 increased by $4.4 \%$ from 2018 and amounted to USD 5.076 trillion. It was a strong year for the US retail market, with growth of $2.9 \%$ in the prior year. 
Table 1. Volume of retail e-commerce and its share in the volume of US retail trade for the period 2015-2019

\begin{tabular}{|c|c|c|c|c|}
\hline Year & $\begin{array}{c}\text { US e-commerce retail } \\
\text { sales, US \$ billion }\end{array}$ & $\begin{array}{c}\text { Growth } \\
\text { rate, \% }\end{array}$ & $\begin{array}{c}\text { Share of e-commerce } \\
\text { sales in US retail sales, } \%\end{array}$ & $\begin{array}{c}\text { Growth } \\
\text { rate, \% }\end{array}$ \\
\hline 2015 & 359,96 & 13,2 & 6,1 & 10,9 \\
\hline 2016 & 397,61 & 14,5 & 6,6 & 8,2 \\
\hline 2017 & 439,25 & 14,0 & 7,5 & 13,6 \\
\hline 2018 & 489,94 & 14,9 & 8,2 & 9,3 \\
\hline 2019 & 542,29 & 10,8 & 9,1 & 11,0 \\
\hline
\end{tabular}

In 2019 , the share of e-commerce in total retail sales in the United States was $9.1 \%$, down 0.9 p.p. up from 2018, when e-commerce sales accounted for $8.2 \%$ of total retail sales. From 2015, when the share was $6.1 \%$, until 2019, the share increased by $3 \%$. The growth is small and the traditional form of trade still prevails.

According to the US Census Bureau, the volume of e-commerce in the first quarter of 2018 was \$ 123 billion. USA, up 3.4\% on Q4 2017 [3, 4].

Analysis of the data allows us to conclude that the volume of e-commerce was growing rapidly in the period under study. There are several reasons for this process. The slow but steady economic recovery is gaining momentum, consumers are becoming more confident about the future, which is generating strong consumer sentiment and opportunity. The ongoing change in the demographic structure of society, in which the proportion of people who are accustomed to shopping on the Internet is increasing, as well as constant technological modernization, the creation of new channels for online orders, leads to an increase in the number of people making purchases, as well as the volume of online sales. The constant increase in the number of online companies is also important. That being said, the bulk of e-commerce profits come from the growth of web leader Amazon as it continues to gain American consumer loyalty and expand into new markets. It should be noted that there are active investments in various electronic platforms, both fully electronic retail companies and companies combining traditional and electronic formats. The growth in online sales of the latter group is driving overall growth in e-commerce sales as omnichannel sales remain the key to success for retail brands [11, 12].

US online store sales grew $44 \%$ in the second quarter of 2020 , or $\$ 62$ billion. to the same period in 2019. This is the largest leap in the history of data collection. Amid the closure of offline stores, the share of sales in the e-commerce market soared from 12 to 16$17 \%$. This growth in sales has spurred the COVID-19 pandemic and the self-isolation regime [5].

The largest consumption occurs at a time when US companies offer big discounts, such as Black Friday, Cyber Monday, and holiday periods.

The development of e-commerce in the United States is influenced by the level of Internet penetration and, as a result, an increase in the number of visitors to online stores and online buyers.

The US is made up of globally-minded consumers who are familiar with online shopping. American youth (18-34) remain the most important consumer group in the ecommerce market, spending more time online than any other age group. At the same time, women are more likely to use electronic shopping than men.

Customer satisfaction and trust are relatively high in the US, but customer expectations are also high. The United States is largely similar to European markets and European consumer behavior.

American consumers tend to be more impatient than other countries. Therefore, UPS and FedEx are the preferred shipping companies for the United States. Small businesses can also use the US Government Postal Service. 
Most US retailers offer free and increasingly faster shipping options. The vast majority of US consumers are more likely to make a purchase with free shipping included. Also, more than half of consumers are more willing to purchase goods if there is a possibility of free return and exchange.

Cross-border e-commerce has developed in the United States, and many retailers see this global channel as a way to attract new customers and orders. The USA is one of the largest cross-border B2C e-commerce markets. The most popular countries for online shopping are China, UK and Canada, for online sales - China, UK and Australia. The intense B2C e-commerce trade between the US and Canada is due to its close geographic location and is also the result of a common language background, as with the UK and Australia.

The most popular categories in cross-border e-commerce are: apparel and accessories, electronics, household goods. At the core of every e-commerce business is a platform that manages a store to improve its performance [6].

Japan's e-commerce market is $\$ 89 \mathrm{bn}$. Almost the entire Japanese Internet audience, which accounts for $80 \%$ of the total population, makes purchases from online stores. Moreover, $6 \%$ of purchases come from tablets, $46 \%$ - from smartphones, $48 \%$ - from stationary computers. Recent studies show that Japanese consumers today spend more time at home than ever before, which means they spend less time shopping in traditional stores. This opens up great opportunities for online retailers. However, it is worth considering that the Japanese approach the choice of a trading platform with all responsibility, giving preference only to reliable sellers with a good reputation, offering quality products.

The UK is ranked fourth in the ranking of e-commerce markets. The size of the ecommerce market in the UK is $\$ 79 \mathrm{bn}$. At the same time, $12.1 \%$ of purchases come from tablets, $16.5 \%$ - from smartphones, $71.4 \%$ - from stationary computers. Online shopping in this country accounts for $30 \%$ of the country's economy, and online sales - more than $13 \%$ of the total retail sales. Most Britons use PayPal, debit and credit cards to pay for goods online. $70 \%$ of UK consumers have a smartphone, but only $16.5 \%$ use it to shop [7].

The fifth largest e-commerce market is Germany, where $85 \%$ of the population is Internet users and online sales are $\$ 74$ billion. At the same time, $11.5 \%$ of purchases come from tablets, $16.2 \%$ - from smartphones, $72.3 \%$ - from stationary computers. Among online retailers, the most popular among Germans are Amazon and Otto, the German marketplace. Small and medium businesses find it difficult to compete with such giants, but there is a way out. The most popular online shopping destination in Germany is fashion. Thus, if you have a small fashion store, you can develop quite successfully in the German market. When promoting an online store, it should be borne in mind that despite the high degree of Internet penetration, German residents are not very active in social networks. So, for example, only $17 \%$ of users check their Facebook in the morning. The Germans pay much more attention to e-mail. The ability to return a product is of great importance to German consumers. Germany has a very high return rate - up to $50 \%$ of all orders are sent back to the store. Therefore, in order for customers to be satisfied, online stores operating in Germany, it is important to think over a return system and organize free shipping.

The next position is occupied by South Korea, the volume of the e-commerce market of which is 66 billion dollars. At the same time, 1\% of purchases come from tablets, $50 \%$ from smartphones, $49 \%$ - from stationary computers. This country has the highest internet speed in the world and on average there are up to 5 credit cards per South Korean resident. For comparison, in the US, everyone has an average of 2 cards. This explains the high credit debt of Koreans. South Koreans prefer sales and promotions. Residents of South Korea often buy American goods, this is due to the fact that South Korean products are nine times more expensive than foreign counterparts. 
The French e-commerce market is $\$ 43$ billion. At the same time, $8.1 \%$ of purchases come from tablets, $11.1 \%$ - from smartphones, $80.8 \%$ - from stationary computers. It should be noted that only $70 \%$ of French people use the Internet and 19\% of purchases are made on foreign sites. This is significantly less than in the UK, USA, Germany and China. Also, French people spend less money on online shopping than residents of these countries. However, France ranks seventh in terms of e-commerce market size, ahead of India, Russia and Canada.

The Indian market is the largest emerging e-commerce market. Despite the fact that Internet penetration in the country is just over $15 \%$, the volume of Internet commerce is constantly growing. The most popular among the population are such areas as electronics and fashion. Along with the growing number of online shoppers, so too is the number of mobile users in India. Most purchases are now made via a mobile device. The main problem in the Indian e-commerce market is shipping. In most of the country, infrastructure is poorly developed, especially in rural areas.

The volume of the e-commerce market in Russia is 31 billion dollars. At the same time, $12 \%$ of purchases come from tablets, $8 \%$ - from smartphones, $80 \%$ - from stationary computers. About $15 \%$ of Russians shop online. Mostly to save money and time. The most popular product categories are electronics, apparel and footwear. The main difficulties faced by e-commerce enterprises in Russia are the lack of access to high-speed Internet in some regions and the undeveloped road infrastructure. Unlike residents of other countries represented in the ranking, Russians prefer to pay for purchases in cash upon delivery.

Canada closes the top ten largest countries in the e-commerce sector, with a market size of $\$ 25$ billion. At the same time, $7.5 \%$ of purchases come from tablets, $8.7 \%$ - from smartphones, $83.8 \%$ - from stationary computers. About $50 \%$ of purchases occur on foreign websites. The reason for this is the high prices for local goods, which, with a similar quality, cannot compete with cheaper American and Chinese goods. In addition, foreign online retailers offer a wider assortment than Canadian stores.

In the future, the development of electronic commerce will be influenced by two opposite factors. On the one hand, global GDP and, accordingly, trade volumes will fall. On the other hand, the electronic segment of B2B commerce will grow at an outstripping pace, both under the influence of the significant advantages of online commerce, and in connection with the pandemic, which disrupted the usual communications based on personal communication between corporate sellers and buyers.

It should be noted that the conversion of business requests is three times higher than that of retail. If in the B2B segment $10 \%$ of visitors to an online store make a purchase, then in $\mathrm{B} 2 \mathrm{C}$ - only 3\%. Business shoppers know exactly what they need and shop regularly. In doing so, they usually purchase hundreds, even thousands of products in one transaction [9, $10]$.

The volume of sales of the global e-commerce market in the B2B segment is increasing annually, as shown in Figure 3.

The global B2C e-commerce turnover in 2019 exceeded $\$ 2$ trillion, showing an average annual growth of $11 \%$.

The well-known consulting and analytical firm A.T. Kearney compiled a rating of countries in terms of e-commerce efficiency based on four indicators: the size of the online market, consumer behavior, growth potential and infrastructure created (Table 2).

The leader of the rating is the United States of America, followed by China, Russia, with a slight lag, in turn, occupies a rather high 8th place in terms of the attractiveness of the online market. 


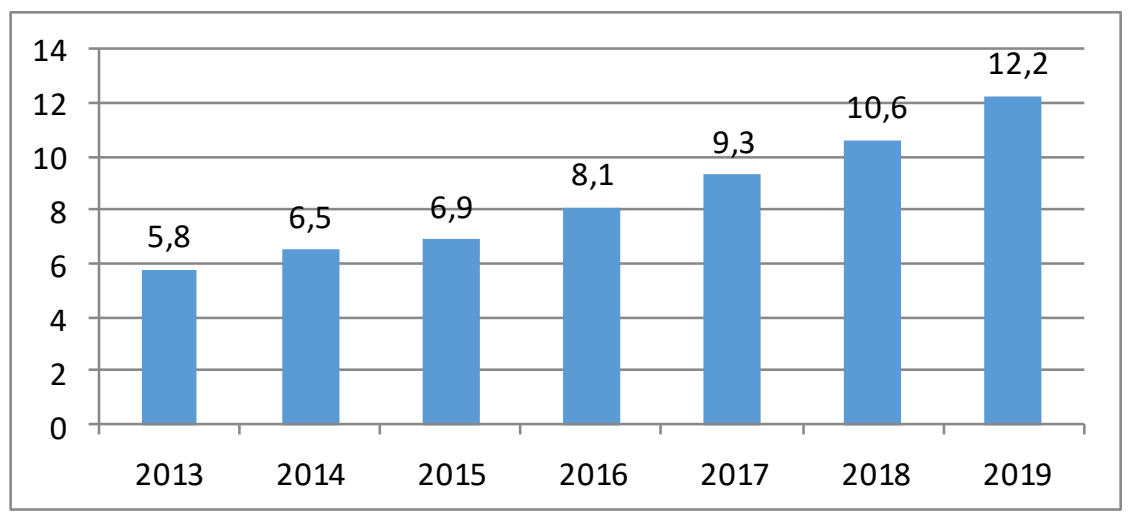

Fig. 3. The global e-commerce market in the B2B segment, billion dollars

In 2019 , there are about 5.56 billion people in 44 countries covered by the report, which is 30 million more than in 2018. Almost half of this population $(47 \%)$ are economically active people aged $25-54$.

Table 2. Ranking of countries in terms of e-commerce efficiency

\begin{tabular}{|c|l|c|c|c|c|}
\hline Rank & Country & $\begin{array}{l}\text { Online market } \\
\text { size }(40 \%)\end{array}$ & $\begin{array}{l}\text { Consumer } \\
\text { behavior } \\
(20 \%)\end{array}$ & $\begin{array}{l}\text { Growth potential } \\
(20 \%)\end{array}$ & $\begin{array}{l}\text { Infrastructure } \\
(20 \%)\end{array}$ \\
\hline 1 & USA & 100,0 & 83,2 & 22,0 & 91,5 \\
\hline 2 & China & 100,0 & 59,4 & 86,1 & 43,6 \\
\hline 3 & Great Britain & 87,9 & 98,6 & 11,3 & 86,4 \\
\hline 4 & Japan & 77,6 & 87,8 & 10,1 & 97,7 \\
\hline 5 & Germany & 63,9 & 92,6 & 29,5 & 83,1 \\
\hline 6 & France & 51,9 & 89,5 & 21,0 & 82,1 \\
\hline 7 & South Korea & 44,9 & 98,4 & 11,3 & 95,0 \\
\hline 8 & Russia & 29,6 & 66,4 & 51,8 & 66,2 \\
\hline 9 & Belgium & 8,3 & 82,0 & 48,3 & 81,1 \\
\hline 10 & Australia & 11,9 & 80,8 & 28,6 & 84,8 \\
\hline
\end{tabular}

Accordingly, the number of Internet users is also growing: in 2015 , only $49 \%$ of the world's inhabitants used the Internet. In 2019, this figure reaches $61 \%$. The highest Internet penetration rates are in Europe at $85 \%$ and in North America (84\%). The lowest is in Southeast Asia and Oceania. However, the population here is the largest - more than 3.4 billion people, many of whom, over time, may become Internet users and, accordingly, buyers.

China since 2010 is the largest trading partner of Russia. Today Russia and China have achieved the strengthening of trade and economic ties. In the entire history of existence, the best relations in all areas are developing right now.

In recent years, a constantly growing trend can be noted in the volume of mutual trade (Figure 4). In 2018, the increase amounted to \$ 19.6 billion. According to Rosstat data, this indicator increased significantly by the end of 2019 and reached a record 108.1 billion. According to forecasts of the Ministry of Economic Development of the Russian Federation, bilateral trade between Russia and China in 2020 may reach 200 billion. dollars, including through the introduction of new e-commerce technologies. The volume of e-commerce between countries in 2017 amounted to 3.5 billion dollars, and in 2018 - 5 billion dollars [8]. 


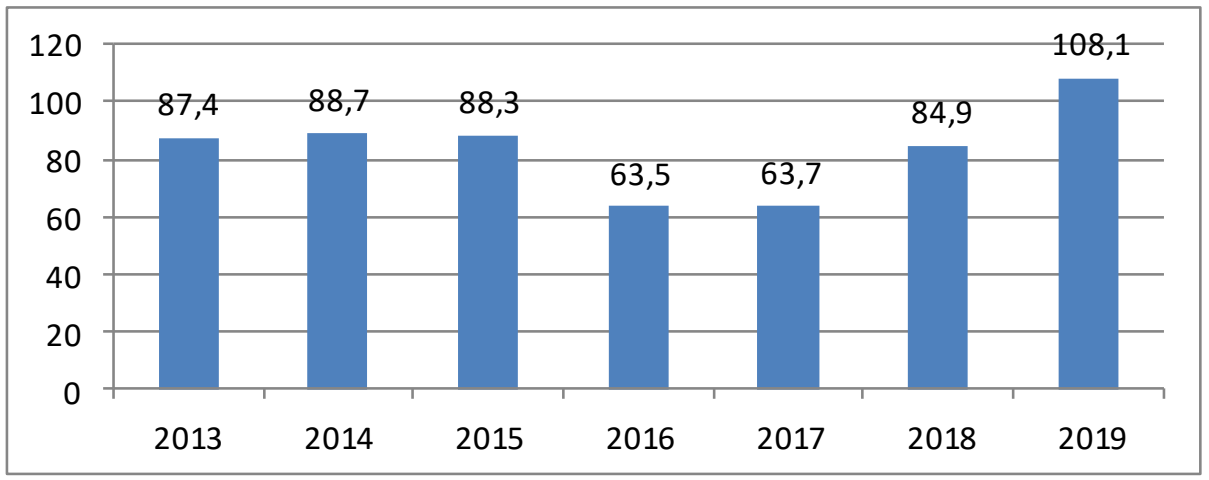

Fig. 4. Dynamics of mutual trade between Russia and China in 2013-2019, billion US dollars

Thus, the fact of progressive development of e-commerce in the markets of foreign countries becomes indisputable. Of course, it cannot be said that the e-commerce market will completely replace and displace real retail and wholesale trade, but it can compete with them.

\section{References}

1. V. Trushin Global development of e-commerce IPG. Research. No. 3. https://rgud.ru/documents/2020-IPG.Research_E-commerce.pdf (2020)

2. Z. Zhou Lin. E-commerce is becoming the core of China's digital economy https://rg.ru/2019/09/02/elektronnaia-kommerciia-stanovitsia-iadrom-cifrovojekonomiki-kitaia.html (2019)

3. Official website of the Association of E-commerce Companies. https://akit.ru/top10_ecommarket (2020)

4. A global business data platform. https://www.statista.com/ (2020)

5. E-commerce Magazine https://e-pepper.ru/news/onlayn-torgovlya-v-ssha-postavilarekord-rosta.html (2020)

6. O. Gavrushin New directions of development of cross-border electronic commerce. Russian Foreign Economic Bulletin. No. 6. https://cyberleninka.ru/article/n/novyenapravleniya-razvitiya-transgranichnoy-elektronnoy-torgovli (2019)

7. N. Khavanova Analysis of the world and Russian e-commerce market: trends and problems of development. Service in Russia and abroad. 136-148 (2020)

8. Denisov A. The volume of cross-border electronic trade of the Russian Federation and China in $2018 \mathrm{http} / / /$ biang.ru/ru/news/obem-transgranichnoj-elektronnojtorgovli-rf-iknr-v-2018-g-prevyisit-\$4-mlrd-posol.html (2018)

9. A. Shinkevich, S. Kudryavtseva, I. Ershova Modelling of energy efficiency factors of petrochemical industry, International Journal of Energy Economics and Policy, 10(3), pp. 465-470 (2020)

10. I. Ershova, O. Belyaeva, A. Obukhova Investment in human capital education under the digital economy, Economic Annals-XXI 180 (11-12), pp. 69-77 (2019)

11. T. Kolmykova, E. Merzlyakova, V. Bredikhin, T. Tolstykh, O. Ovchinnikova Problems Of Formation Of Perspective Growth Points Of High-Tech Productions. Advances in Intelligent Systems and Computing. V. 622. Pp. 469-475 (2018).

12. T. Kolmykova, E. Merzlyakova The role of humans in the development of modern robotic reproduction. Економічний часопис-XXI. 11-12. Pp.183-190. (2019). 